УДК 316.4:343.08

НЕСТЕРОВ Артем Юрьевич - кандидат социологическихнаук, старший преподаватель Московского государственного университета технологий и управления им. К.Г. Разумовского (ПКУ) (109004, Россия, г. Москва, ул. Земляной Вал, 73; пе7terov@rambler.ru)

\title{
ПЕНИТЕНЦИАРНАЯ РЕСОЦИАЛИЗАЦИЯ НЕСОВЕРШЕННОЛЕТНИХ ОСУЖДЕННЫХ: ОСНОВНЫЕ ПОНЯТИЯ, ЗАКОНОМЕРНОСТИ И ПРАВОВАЯ ОСНОВА (ВОПРОСЫ ТЕОРИИ И ПРАКТИКИ)
}

\begin{abstract}
Аннотация. В статье анализируются основные понятия, закономерности и правовая основа пенитенциарной ресоциализации несовершеннолетних осужденных в учреждениях ФСИН России. Автор определяет понятие «пенитенциарная ресоциализация несовершеннолетних осужденных», его сущность и особенности в УИС России. По мнению автора публикации, остро стоит вопрос о необходимости создания территориальных ФСП России во всех субъектах РФ как нового органа исполнительной власти на федеральном уровне.
\end{abstract}

Ключевые слова: преступность несовершеннолетних, безнадзорность и беспризорность, несовершеннолетние осужденные, пенитенциарная ресоциализация осужденных, УК РФ, УИК РФ, УИС России, воспитательные колонии ФСИН России

$\Pi$ реступность несовершеннолетних - одна из важных проблем современного российского общества. Необходимо переосмыслить меры предупреждения преступности несовершеннолетних осужденных, находящихся в местах лишения свободы. Подростки все чаще совершают преступления ради корысти, развлечений, из-за экономических трудностей. Среди преступлений, совершаемых несовершеннолетними, велика доля тяжких корыстных и корыстно-насильственных преступлений. Нередко им присущи черты вандализма, чрезмерной жестокости. Почти половина этих преступлений совершаются в соучастии (чаще всего в форме соисполнительства), особенно в группе, что также отвечает специфике психологии подростков-осужденных. Примерно каждое третье преступление совершается ими совместно со взрослыми правонарушителями [Башкатов 2013: 21].

Также можем отметить то, что преступность несовершеннолетних зависит от благополучия региона. Условия жизни в регионе напрямую отражают динамику преступности несовершеннолетних. Например, в Кемеровской, Омской, Новосибирской, Томской обл. чаще совершаются такие виды уголовных правонарушений, как «незаконное завладение транспортным средством без цели хищения», ст. 166 ч. 1 УК РФ (на 8,8\% больше, чем в СФО); «захват заложников», ст. 206 УК РФ (в общеобразовательных учреждениях - с целью отомстить ровесникам и педагогам за систематическое надругательство над личностью); «вымогательство либо хищение наркотических средств или психотропных веществ», ст. 229 УК РФ (на 22,7\% больше, чем в СФО) и т.д.

В УК РФ (1996 г.) выделен раздел V, посвященный уголовной ответственности несовершеннолетних - глава 14 «Особенности уголовной ответственности и наказания несовершеннолетних» 1 . Преступность несовершеннолетних охваты-

\footnotetext{
1 Уголовный кодекс Российской Федерации от 13.06.1996 № 63-Ф3 (ред. от 31.12.2017). Доступ: http://www.consultant.ru/document/cons_doc_LAW_10699/
} 
вает определенный возраст (14 - 18 лет), конкретную территорию и промежуток времени. Именно эти критерии и отличают преступность несовершеннолетних от преступлений взрослых [Алексеева 2014: 1].

Традиционно остро стоит проблема несовершеннолетнего осужденного, его жизни в обществе до и после отбывания уголовного наказания в виде лишения свободы. Безразличное отношение к проблемам лиц, осужденных к лишению свободы, существовавшее начиная со времен ГУЛАГа, сейчас уже мало кого устраивает, однако в России в настоящее время предпринимается явно недостаточно решительных мер для изменения этой ситуации [Перминов 1999: 122].

Безнадзорность и беспризорность несовершеннолетних остаются тревожными характеристиками современного российского общества. Подростковая безнадзорность - это отсутствие должного контроля и надзора со стороны семьи и образовательных учреждений за поведением, связями, времяпрепровождением несовершеннолетнего. Безнадзорность также может быть следствием неумения или нежелания родителей (либо лиц, их заменяющих) выполнять свои обязанности по воспитанию детей, а также плохого микроклимата в семье. Это может быть отсутствие должной требовательности к ребенку, неопределенность круга его обязанностей, отсутствие контроля за его учебой и досугом. Игнорирование родителями необходимости следить за кругом знакомств ребенка приводит к возникновению наиболее опасных форм безнадзорности, когда ребенок попадает в криминогенные компании. По нашему мнению, безнадзорность как одна из основных причин преступности несовершеннолетних есть нарушение неотъемлемых прав ребенка на адекватное воспитание, семейное окружение и развитие прав несовершеннолетнего. Беспризорность - это уже следствие безнадзорности, она включает в себя все разновидности девиантного поведения несовершеннолетнего, например разбойные налеты, групповые кражи и др.

Несмотря на то что современное российское общество стало более гуманным и толерантным, несовершеннолетние осужденные, отбывавшие наказание в местах лишения свободы, воспринимаются обществом как отверженные. Так, 84,7\% респондентов в ходе нашего социологического исследования в 2014-2018 гг. убеждены, что от несовершеннолетних осужденных, отбывавших уголовное наказание в воспитательных колониях ФСИН России, нет и не будет никакой пользы, они неисправимы. Более $70 \%$ уверены, что подростки после освобождения из воспитательной колонии вновь совершат преступление и вернутся в места лишения свободы. Только 9,8\% респондентов считают, что опыт, полученный вследствие осуждения, и нахождение в местах лишения свободы исправят подростка. 5,5\% респондентов затруднились ответить на данный вопрос: по их мнению, это очень сложно сегодня утверждать, т.к. «мы не знаем, в какой семье они воспитывались... куда они вернутся после освобождения из колонии... какие условия их ожидают в постпенитенциарный период». Успешной адаптации несовершеннолетних осужденных в постпенитенциарный период, естественно, мешают не только затруднения при поиске официальной работы, попытке создания семьи, приобретения собственного жилища, но и негативное отношение к таким лицам как со стороны служащих государственных (муниципальных) органов исполнительной власти, так и со стороны простых граждан.

Как правило, основную группу лиц, нуждающихся в социальной адаптации в постпенитенциарный период, образуют несовершеннолетние осужденные, освободившиеся из воспитательных колоний ФСИН России. По нашему мнению, оказание содействия в социальной адаптации после освобождения 
из пенитенциарного учреждения - в первую очередь в интересах самого подростка-осужденного, но также и в интересах всего российского общества. Если подростки не встанут вновь на путь преступления, искоренится сама сущность рецидивных противоправных действий, совершаемых несовершеннолетним осужденным в отношении индивидов, общества и государства в целом [Пищелко 2012: 163].

Пенитенциарная ресоциализация несовершеннолетних осужденных, отбывших и отбывающих уголовное наказание в виде лишения свободы в учреждениях ФСИН России, - это в первую очередь сознательное восстановление (исправление) несовершеннолетнего осужденного в социальном и правовом статусе полноправного члена современного российского общества, а также возвращение его к самостоятельной общепринятой социально-нормативной жизни в обществе. Лишение свободы несовершеннолетних осужденных является одной из актуальных проблем в процессе пенитенциарной ресоциализации осужденного в условиях закрытого учреждения ФСИН России. Это обусловлено прежде всего тем, что более 50-70\% учреждений данного типа сегодня не готовы к революционным подходам к пенитенциарной ресоциализации осужденных. Условия содержания несовершеннолетних осужденных, обращение с ними не соответствуют мировым стандартам, как этого требует международное право в отношении несовершеннолетних осужденных, находящихся в местах лишения свободы (Пекинские правила, 1985). В минимальных стандартных правилах обращения с заключенными прямо указывается, что подготовка несовершеннолетнего осужденного к освобождению - это длительный процесс, который начинается с первого дня его заключения под стражу. Результаты работы по адаптации несовершеннолетних осужденных к жизни в обществе зависят от тщательного планирования этой работы администрацией пенитенциарного учреждения и от продолжительности контактов осужденных с их родственниками.

Как было отмечено ранее, необходимым условием пенитенциарной ресоциализации несовершеннолетних осужденных, находящихся в местах лишения свободы, является исправление (восстановление), а также возвращение в социум подростка-осужденного как полноправного члена общества. Далее определим основные средства пенитенциарной ресоциализации несовершеннолетних осужденных, находящихся в местах лишения свободы.

Во-первых, это установленный порядок исполнения и отбывания уголовного наказания в виде лишения свободы. В соответствии с УИК РФ определено четыре вида режимных условий пребывания осужденных в воспитательных колониях ФСИН России: строгий, обычный, облегченный, льготный режимы ${ }^{1}$.

Во-вторых, это общественно-полезный труд осужденных в воспитательных колониях ФСИН России, социально-воспитательная работа с несовершеннолетними осужденными, общеобразовательное и профессионально-техническое обучение с целью профориентации в постпенитенциарный период, а также общественное влияние на осужденных через деятельность различных НКО, благотворительных фондов (волонтерское служение) и религиозных организаций (РПЦ).

Как нам известно из ч. 1-3 ст. 9 УИК РФ, все средства исправления и ресоциализации несовершеннолетних осужденных применяются с учетом вида наказания, личности осужденного, характера, степени общественной опасности и

1 Уголовно-исполнительный кодекс Российской Федерации от 08.01.1997 № 1-Ф3 (ред. от 20.12.2017). Ст. 132. Доступ: http://www.consultant.ru/document/cons_doc_LAW_12940/ 
мотивов совершенного уголовного преступления и поведения осужденного во время отбывания уголовного наказания в виде лишения свободы ${ }^{1}$.

Также можно отметить, что сегодня пенитенциарная ресоциализация осужденных во всех видах учреждений ФСИН России рассматривается как одно из основных направлений деятельности органов и учреждений ФСИН России, способствует воспитанию (исправлению) у осужденных (в т.ч. и несовершеннолетних) социально адекватных качеств. Она является внутренним процессом положительных изменений в личности осужденного в результате его сотрудничества с персоналом и администрацией учреждений ФСИН России. Цель наказания является в первую очередь карательной, и только потом - воспитательной.

Пенитенциарная ресоциализация осужденного через законодательные нормы, такие как «исправление» и «ресоциализация» осужденного, определенные в ч. 1 ст. 9 УИК РФ (1997), рассматривается законодателем как процесс позитивных изменений, которые происходят в его личности. В процессе предполагаемой позитивной пенитенциарной ресоциализации несовершеннолетних осужденных, находящихся в учреждениях ФСИН России, «формируется уважительное отношение в первую очередь к сверстнику-осужденному, а также к сотруднику колонии (индивиду общества), обществу в целом, ОПТ, нормам, правилам, ценностям и традициям человеческого общежития и стимулирование правопослушного поведения» 2 . Для достижения данной цели в процессе пенитенциарной ресоциализации во всех воспитательных колониях ФСИН России осуществляется непременное выполнение следующих задач: 1) повышение общеобразовательного уровня несовершеннолетних осужденных в общеобразовательной (сменной) вечерней школе в обязательном порядке 3 ; 2) профессиональное обучение либо повышение производственной квалификации в ПУ при воспитательной колонии ФСИН России 4 ; 3) охрана здоровья, приучение к порядку и условиям, установленным в учреждениях ФСИН России 5 ; 4) обеспечение возможности и оказание квалифицированной юридической и социальной помощи, а также помощи в установлении и поддержании социально полезных связей, подготовка к освобождению6 [Перминов 1999: 189].

Пенитенциарная ресоциализация несовершеннолетних осужденных, отбывающих срок лишения свободы в учреждениях ФСИН России, достаточно трудна, поскольку у них произошла утрата практически всех социальных связей

1 Уголовно-исполнительный кодекс Российской Федерации от 08.01.1997 № 1-Ф3 (ред. от 20.12.2017). Доступ: http://www.consultant.ru/document/cons_doc_LAW_12940/

2 Там же.

3 Уголовно-исполнительный кодекс Российской Федерации от 08.01.1997 № 1-Ф3 (ред. от 20.12.2017). Ст. 112; Федеральный закон «Об образовании в Российской Федерации» от 29.12.2012 N 273-ФЗ. Доступ: http://www.consultant.ru/document/cons_doc_LAW_140174/; Приказ МЮ РФ № 274 и МОиН РФ № 1525 от 06.12.2016 «Об утверждении порядка организации получения начального общего, основного общего и среднего общего образования лицами, отбывающими наказание в виде лишения свободы». Доступ: https://normativ.kontur.ru/document?moduleId=1\&documentId=285593

4 Уголовно-исполнительный кодекс Российской Федерации от 08.01.1997 № 1-Ф3 (ред. от 20.12.2017). Ст. 108; Федеральный закон «Об образовании в Российской Федерации» от 29.12.2012 N 273-Ф3.

5 Уголовно-исполнительный кодекс Российской Федерации от 08.01.1997 № 1-Ф3 (ред. от 20.12.2017). П. 6 ст. 12; Приказ Минюста России от 06.10.2006 N 311 (ред. от 29.12.2017) «Об утверждении Правил внутреннего распорядка воспитательных колоний уголовно-исполнительной системы». Доступ: http://legalacts.ru/doc/prikaz-miniusta-rf-ot-06102006-n-311/; Приказ МЮ РФ № 95 от 23.06.2005 «Об утверждении Инструкции о надзоре за осужденными, содержащимися в воспитательных колониях Федеральной службы исполнения наказаний». Доступ: http://sbornik-zakonov.ru/100974. html

6 Уголовно-исполнительный кодекс Российской Федерации от 08.01.1997 № 1-Ф3. П. 7, 8 ст. 12; ст. 180. 
и общественно полезных качеств. В данном случае, как указывает М.С. Рыбак, пенитенциарная ресоциализация осужденного имеет три основных аспекта: это, во-первых, вторичная социализация, определяемая как ресоциализация - освобождение от вредных «тюремных» привычек и получение полезных социальных навыков в условиях УИС России. Данный процесс затруднителен (практически невыполним) на первых двух этапах: 1) пенитенциарной адаптации в условиях СИЗО ФСИН России и 2) в «строгом» и «общем» режимных условиях воспитательной колонии ФСИН России. Это обусловлено тем, что субъект уголовно-исполнительного права только выходит из «криминального куража», а также происходят новые криминальные знакомства, формируется неформальный статус, в котором подросток и проведет основной срок в местах лишения свободы. Во-вторых, это пенитенциарная (социальная) адаптация - приспособление к изменившимся жизненным условиям в местах лишения свободы. И в-третьих, это социальная реабилитация в постпенитенциарный период - восстановление утраченного гражданского и социального статуса в обществе) [Пищелко 2012: 168].

Определяя такую социальную дефиницию, как «пенитенциарная ресоциализация осужденного», подчеркнем, что, во-первых, это сознательное восстановление осужденного в социальном статусе как полноправного члена современного российского общества; во-вторых, это восстановление социальнополезных связей между осужденным и его близкими; в-третьих, это возвращение осужденного к самостоятельной общепринятой социально-нормативной жизни в социуме.

Также под пенитенциарной ресоциализацией несовершеннолетних осужденных, находящихся в учреждениях ФСИН России, понимается длительный процесс исполнения уголовного наказания в виде лишения свободы, имеющий в своей основе сложный (специфический, порой и противоречивый) комплекс психолого-педагогических, медицинских, экономических, юридических и организационных мер в учреждениях ФСИН России, направленных на формирование у каждого осужденного способности и готовности к более-менее благополучной социальной адаптации в социум в постпенитенциарный период.

По мнению В.Ф. Иванова и др., несовершеннолетний, осужденный к лишению свободы, в первую очередь определяется как личность, которая претерпевает значительные изменения (как психологические, так и физиологические) в условиях УИС России, в результате которых наибольшую значимость для него приобретают ценности, обеспечивающие индивидуальное, как бы внесоциальное существование, а ценности, отражающие деятельностную и социальную сущность индивида, уходят на второй план [Иванов, Малько, Рыбак 2010: 103].

По определению уголовно-исполнительного законодательства России, несовершеннолетний осужденный по окончании срока уголовного наказания освобождается из мест лишения свободы и входит в общество уже как специфическая личность (личность, имеющая опыт общения в криминальной сфере, личность с особыми порядками, устоями и взглядами на жизнь). Но по освобождении из мест лишения свободы УИП России в первую очередь предусматривает, что он обязан соблюдать основные законы и нормы общежития. Однако в силу ряда специфических причин (например, возвращение в прежнюю криминальную среду) подросток быстро утрачивает навыки пенитенциарной ресоциализации, приобретенные в воспитательной колонии, и вновь вовлекается в преступную деятельность с более расширенными границами. К сожалению, таков основной исход данной ресоциализации несовершеннолетних осужденных - более 75,8\%. Сложность проблемы заключается в том, что, освободившись из воспитательной колонии, несовершеннолетние осужденные попадают в ту 
же микросреду, в которой они обитали до осуждения, либо приобретают новые криминальные знакомства в период отбывания уголовного наказания, и это не позволяет реализоваться их глубинной положительной ориентации, заложенной в пенитенциарном учреждении ФСИН России.

Основная цель исследования подтвердить (или опровергнуть) сущность успешной социальной адаптации несовершеннолетних осужденных в постпенитенциарный период. По нашему мнению, успешность постпенитенциарной адаптации осужденных, как показывают и практика, и исследования, зависит от следующих факторов: во-первых, это вовлечение подростка, освободившегося из мест лишения свободы, в ОПТ или волонтерскую деятельность (с гарантированной оплатой труда и соцпакетом), а также одновременно продолжение профессионального обучения в рамках реализуемых программ СПО и ВПО; во-вторых, в процессе отбывания уголовного наказания в местах лишения свободы по возможности следует устанавливать (восстанавливать) семейные (родственные) отношения и/или иные социально полезные связи (для детей-сирот и детей, оставшихся без попечения родителей), а также восстанавливать положительно окрашенные коммуникативные социальные связи между сверстниками-осужденными и, по возможности (через различные открытые мероприятия, проводимые в воспитательной колонии и за ее пределами), со сверстниками из школ и колледжей; в-третьих, это укрепление морально-нравственных, культурных ценностей как основополагающего фактора социального поведения индивида в обществе [Никифоров 1968].

Если анализировать состав осужденных, досрочно освобождаемых из воспитательных колоний ФСИН России, с точки зрения степени их исправления, криминальной «зараженности», то можно заметить, что досрочно освобождаются, как правило, лица, исправившиеся (вставшие на истинный путь) или уверенно доказавшие суду свое исправление и готовность положительно доказывать это и далее - через труд и продолжение профессиональной подготовки в образовательной организации [Перминов 1999: 184]. Тогда можно с уверенностью утверждать, что данные осужденные получили необходимую нравственную и психологическую подготовку в процессе пенитенциарной ресоциализации, не потеряли социально полезных связей с семьей и обществом, а также вполне могут успешно вернуться к правопослушной деятельности, освоить новые социальные роли в социуме. Также с большой долей уверенности мы можем утверждать, что начавшийся процесс исправления несовершеннолетнего осужденного может быть успешно завершен при помощи ресоциализационных мер в условиях УИС России. Но для закрепления данного эффекта со стороны государства требуется контролировать процесс первичной социальной адаптации осужденного в постпенитенциарный период, а также, по возможности, оказывать необходимую помощь в трудовом, бытовом и семейном устройстве.

Возникает необходимость создания во всех субъектах РФ территориальных ФСП России, отвечающих за данный аспект социальной адаптации осужденных в постпенитенциарный период. Полагаем, что уголовно-исполнительные инспекции ФСИН России (УИИ ФСИН России) либо вновь образуемый федеральный орган исполнительной власти (ФСП России) как раз и должны стать такими специализированными институтами в России. На последний, в частности, могут быть возложены функции по координации деятельности всех органов и служб по социальной адаптации осужденных, освобожденных и по УДО, и по амнистии в постпенитенциарный период.

Анализируя заключительный процесс пенитенциарной ресоциализации несовершеннолетних осужденных, досрочно освобожденных от отбывания уголовного наказания из воспитательных колоний ФСИН России, можно констати- 
ровать, что данный процесс начинается задолго до освобождения осужденного (за 6 месяцев). И состоит он в основном из подготовки осужденного к самостоятельной жизни за пределами мест лишения свободы (данная подготовка осуществляется в особых режимных условиях - «льготных»). При воспитательной колонии существует реабилитационный центр, который и ориентирован на подготовку осужденного к освобождению из мест лишения свободы. Основная задача проведения данного этапа пенитенциарной ресоциализации осужденных - снять или минимизировать отрицательные последствия, вызванные изоляцией индивида от общества, и подготовить его к предстоящему освобождению из мест лишения свободы.

Однако здесь есть и проблемы. Так, основным недостатком данного этапа заключительной пенитенциарной ресоциализации осужденных является то, что администрация воспитательной колонии ФСИН России зачастую не успевает подготовить (в полной мере социализировать) подростка к моменту освобождения из воспитательной колонии. Зачастую это отражается в подготовке самой личности осужденного к освобождению и вхождению в социум как правопослушного индивида. Это обусловлено многими факторами: неготовностью самого подростка-осужденного исправляться и вставать на путь исправления (личностный фактор); не до конца решенным вопросом о будущем месте жительства подростка (как правило, эта проблема возникает у подростков из числа сирот, не имеющих родителей и родственников), а также о месте учебы и работы и многими другими факторыми (внешние факторы); а также нерешенным вопросом о создании социально-бытовых условий в воспитательной колонии для реализации данной программы (внутренний фактор).

На сам процесс социальной адаптации несовершеннолетних осужденных в постпенитенциарный период влияют немало обстоятельств. Это 1) эффективность исполнения уголовного наказания в виде лишения свободы - «эффект пенитенциарной ресоциализации», который действует на протяжении всего периода пребывания осужденного в пенитенциарном учреждении ФСИН России, его плюсы и минусы; 2) морально-нравственная, социально-педагогическая и психологическая, а также организационная подготовка осужденных к освобождению из воспитательной колонии ФСИН России; 3) осознанное усвоение несовершеннолетними осужденными новых социально полезных ролей после освобождения из воспитательной колонии (получение профессионального образования по различным профессиям в ПУ); 4) восстановление социально полезных связей с близкими и родственниками, правового статуса гражданина (оформление нужных документов, в т.ч. и паспорта гражданина РФ) и многое другое.

\section{Список литературы}

Алексеева Е.А. 2014. Преступность несовершеннолетних: причины и проблемы. - Электронный жмунал Экстернат.РФ. 02.11. Доступ: http://ext.spb.ru/ site/6317-2014-11-02-19-26-25.pdf /

Башкатов И.Л. 2013. Психология групп несовершеннолетних правонарушителей. М.: Норма. 54 с.

Иванов В.Ф. Малько А.В., Рыбак М.С. 2010. Правовое стимулирование исправления осужденных к лишению свободы в современных условиях. Государство и право. № 8. С. 100-107.

Никифоров В.С. 1968. К вопросу об изучении эффективности уголовноправовых мер борьбы с преступностью. - Эффективность уголовноправовых мер борьбы с преступностью (под. ред. Б.С. Никифорова). М.: Юридическая литература. С. 3-19. 
Перминов О. 1999. Уголовно-исполнительное право. М.: Былина. 240 с.

Пищелко А.В. 2012. Психолого-педагогические основы ресоциализации личности осужденных. М.: Домодедово. 250 с.

NESTEROV Artem Yur'evich, Cand.Sci. (Soc.), Senior Lecturer, Moscow State University of Technologies and Management named after K.G. Razumovsky (73 Zemlyanoi Val St, Moscow, Russia, 109004; ne7terov@rambler.ru)

\title{
PENITENTIARY RESOCIALIZATION OF MINOR CONVICTS: BASIC CONCEPTS, REGULARITIES AND LEGAL FRAMEWORK (QUESTIONS OF THEORY AND PRACTICE)
}

\begin{abstract}
The article analyzes the basic concepts, regularities and legal basis of penitentiary resocialization of minor convicts in the FSIN of Russia. The author defines the concept of penitentiary resocialization of minor convicts, its essence and peculiarities in the penitentiary system of Russia. According to the author of the publication, there is an acute need for the creation of territorial FCS of Russia in all constituent entities of the Russian Federation as a new executive body at the federal level.

Keywords: juvenile delinquency, neglect and homelessness, minor convicts, penitentiary resocialization of convicts, Criminal Code of the Russian Federation, the PEC of the Russian Federation, Criminal Penitentiary Service of Russia, FC "VK» of the Federal Penitentiary Service of Russia
\end{abstract}

